\title{
RELATIONSHIP BETWEEN MANGROVE SEEDLING GROWTH, NUTRIENTS AND HEAVY METAL CONCENTRATIONS IN SOIL AT CAREY ISLAND, SELANGOR, MALAYSIA
}

\author{
Rozainah M. Z. ${ }^{\text {ab } b^{*} \text {, Affandi N. A. }}{ }^{\text {b }}$ and Noraini M. T. ${ }^{\text {a }}$ \\ ${ }^{a}$ Institute of Ocean and Earth Sciences, University of Malaya, 50603, Kuala Lumpur, Malaysia \\ ${ }^{\mathrm{b}}$ Institute of Biological Sciences, University of Malaya, 50603 Kuala Lumpur, Malaysia \\ *Corresponding Author: rozainah@um.edu.my
}

\begin{abstract}
A comparative study in the relationship between mangrove seedling growth and heavy metal concentrations in sediment was conducted at Carey Island, Malaysia. Two contrasting stations were chosen; natural habitat and reforestation site. Avicennia alba and Rhizophora apiculata were chosen as the test species. At the reforestation site, R. apiculata showed higher increments of stem height $(1.74 \mathrm{~cm} \mathrm{mth}-1)$ compared to A. alba (1.28 $\mathrm{cm}$ mth-1), although both species produced 1 leaf per month. On the other hand, A. alba showed better increment of height $(2.17 \mathrm{~cm} \mathrm{mth}-1)$ and produced 2 leaves per month in the natural habitat. R. apiculata has very slow growth, at only $0.65 \mathrm{~cm}$ mth- 1 and produced 1 leaf per month. Pearson correlation deducted that A. alba showed positive correlation in growth with $\mathrm{Mg}$ at the reforestation site, and with sulfate and chloride in natural habitat. At the reforestation site, $\mathrm{R}$. apiculata showed positive correlation with $\mathrm{Ca}$ and $\mathrm{Cu}$ but did not record any significant correlation with those elements in the natural habitat.
\end{abstract}

(Keywords: Heavy metal, Straits of Malacca, mangrove, nutrients)

\section{INTRODUCTION}

The Straits of Malacca located between the east coast of Sumatra Island in Indonesia and the west coast of Peninsular Malaysia, is linked with the Strait of Singapore at its southeast end [1]. It is one of the world's busiest commercial shipping lane which on average, 200 ships pass a day [2]. In Malaysia, the Straits of Malacca is the main transport for shipping industries and the major ports include Port Klang, Port Dickson, Ipoh Cargo Terminal, Malacca Port and Penang Port [1]. Inevitably, the heavy shipping traffic has contributed to marine pollution for examples through oil spills by tankers, vessels collisions and sewage discharge. According to Sharina [2], the Straits are eutrophic (enrichment of nutrients) due to the relative high content of particulate organic carbon in the sea water off Port Dickson, compared to Kuala Terengganu on the east coast of Peninsular Malaysia.

Mangrove forest that thrives along the coastal zones acts as a sink of nutrient and heavy metal derived from the river and tidal fluctuation. The exported of nutrients to mangrove ecosystem from land led to nutrients limitation which is influencing the mangrove growth. Mangrove growth faster in balanced of nutritional status [3]. However, across the world, mangrove forest is facing severe coastal erosion caused by deforestation and land reclamation for development, livelihoods and agriculture farms to meet human's needs [4]. These activities changed the mangrove ecosystem as well as its ecological functions. The harmful effect of coastal erosion triggered the Malaysian government to rehabilitate mangrove forest. Thus, a total of $1,507,120$ mangrove seedlings have been planted in 620.29 ha area via conventional method throughout the nation including Sabah and Sarawak with an allocated budget of RM10.5 million [5]. Subsequently, the environmental issues on water quality and marine pollution directly and indirectly affected the growth of planted seedling in rehabilitation areas that are exposed to the open sea. This paper focused on the distribution of nutrient and heavy metal and their relationship with the mangrove seedling growth to justify the need of rehabilitation efforts.

\section{Materials and methods}

\section{Study site}

This study was carried out at Carey Island, Selangor, Malaysia (Figure 1). The fringing mangrove forest was represented by grey-shaded colour, including a thin layer of mangrove forest that required reforestation effort. Carey Island has $1,876.85$ hectares of mangrove area gazetted as Forest Reserve of Selangor [6] within the total area of $16,187.45$ hectares. Sixty percent of the island was planted with oil palm run under the 
management of Sime Darby Plantations Berhad. As Carey Island below sea level, earth bund (dike) was constructed almost along the coastline to prevent saltwater intrusion. The island receives daily tidal inundation and was exposed to the southwest monsoon and the northeast monsoon.

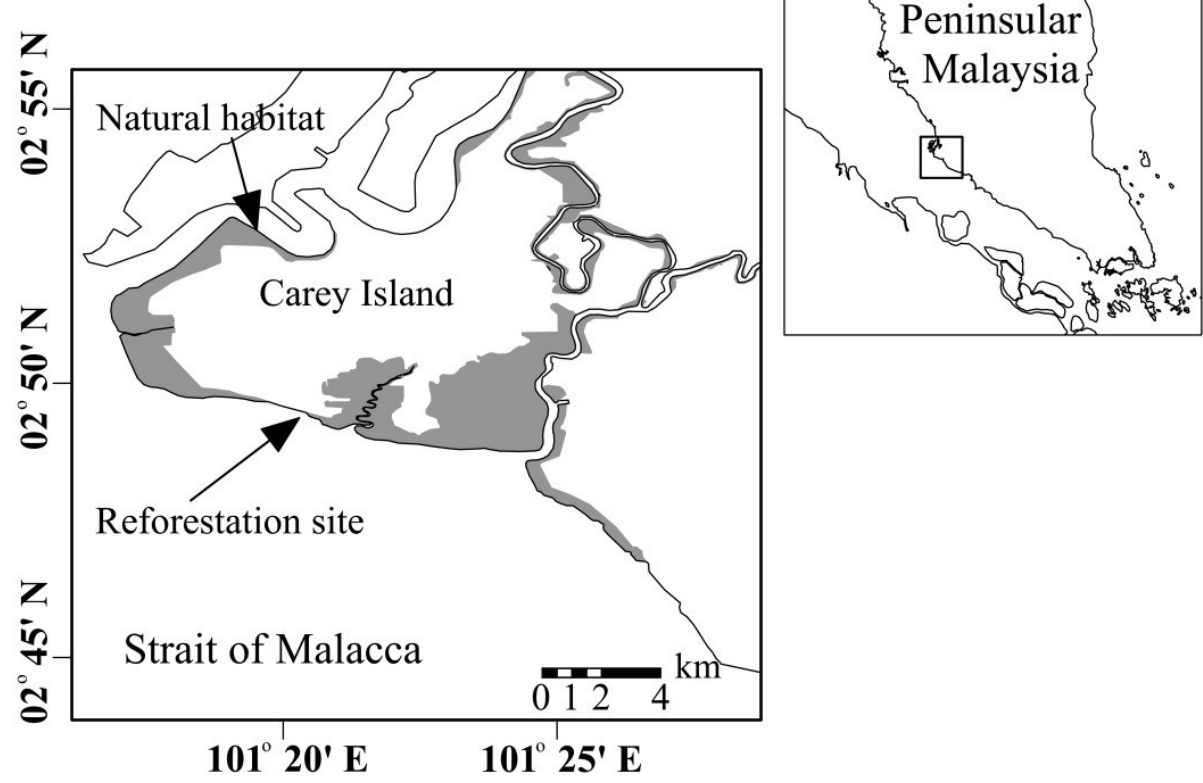

Figure 1. Map of location of Carey Island and both study sites (reforestation and natural habitat sites). Grey shade depicts the mangrove area [7].

\section{Planting method}

In order to provide a suitable environment and to protect the seedlings from the strong wave actions at the rehabilitation site, an eco-engineering technique was applied. A $60 \mathrm{~m}$ long of breakwater was installed at the reforestation site [7]. Additionally, the brush fascines also installed to the east of the breakwater as a sediment trap and act as a secondary wave breaker (Figure 2). A brush fascine was made from the natural brush or shrubs and was tied into bundle.
Three hundred and fourteen of Avicennia alba and 106 of Rhizophora apiculata seedlings were planted at the reforestation site, using coir log. Initially, the seedlings' roots were wrapped around with the loose coconut coir and tied with a cotton strings (plant plug) and inserted into the coir $\operatorname{logs}(200 \mathrm{~mm}$ and $300 \mathrm{~mm}$ in diameter size). Planting seedlings in the coir logs can avoid the seedlings' roots from being damage during the transplantation, and help to provide initial stabilization by protecting the roots from wave action. Figure 2 shows the vegetated coir logs planted in a grid formation behind the breakwater at the reforestation site. 


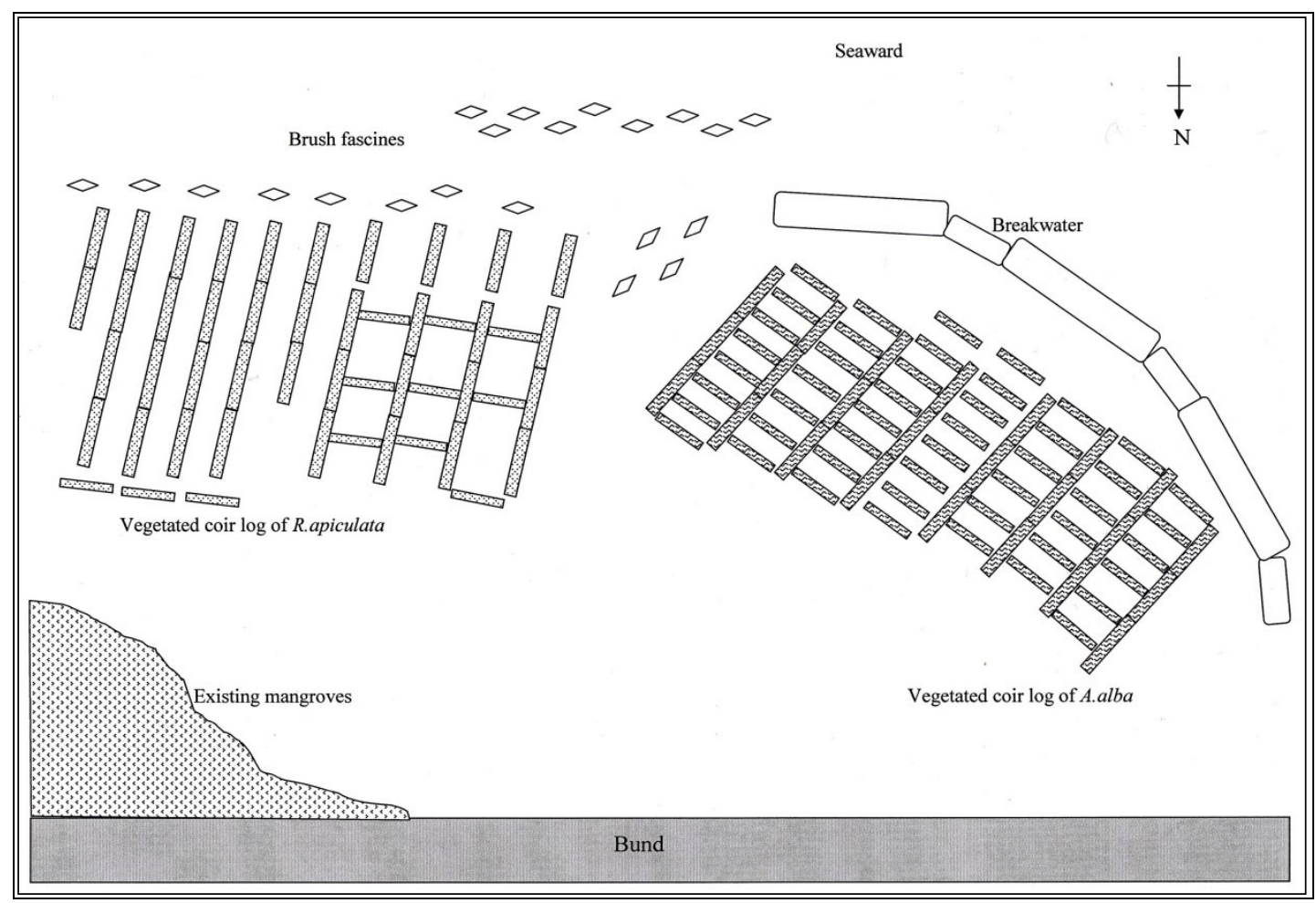

Figure 2. Formation of vegetated coir logs arranged in grid planted behind the breakwater.

\section{Seedlings' growth monitoring}

Seedlings growth was measured by its height and number of leaves on monthly basis by selecting 20 seedlings at random at the reforestation site and natural habitat.

\section{Soil sampling}

Three samples of surface sediment $10 \mathrm{~cm}$ deep were collected from the reforestation site and natural habitat every 3 months at low tide from March to December 2009. The samples were tested for $\mathrm{pH}$, salinity and texture. Nutrient contents (nitrate, sulfate and chloride) were determined using an Ion Chromatography analyzer model Metrohm 861 Advanced Compact IC. Heavy metals contents were detected by using an Ion Coupled Plasma analyzer model Perkin Elmer Optima 5300 DV following the standard method.

\section{Statistical analysis}

The correlation between the growth rate and nutrient and heavy metal concentrations in the soil water at the reforestation site and natural habitat were tested using Pearson Correlation $(\mathrm{P}<0.05)$ by PASW software version 18.0.

\section{Results and discussion}

The $\mathrm{pH}$ values in sediment were almost similar at the reforestation site and natural habitat, with mean value of $7.23 \pm 0.19$ and $714 \pm 0.21$ respectively. Similarly, the salinity was also not so different in both sites, which were ranging from $24.3-29.2$ and $25.7-28.3$ at the reforestation site and natural habitat, respectively. Soil texture at the rehabilitation site was silt loam while the natural habitat was dominated by silt type. Figures 3 and 4 showed the average of nutrient concentration at the reforestation site and natural habitat during the study period.

Sulfate concentrations were recorded similar at the both site. However chloride concentration at both sites showed a higher value in the reforestation site (15.46$32.84 \mathrm{ppt})$ compared to natural habitat (12.08-27.91 ppt). While nitrate concentration at the reforestation site was recorded in the range between 22.69-57.39 ppt. (Figure 3), the natural habitat did not record any appearance of nitrate (Figure 4). The difference could be affected by locations and elevation. The reforestation site was located about $70 \mathrm{~m}$ from the palm oil plantation and lied at lower elevation. Frequent fertilizer application in the plantation could lead to surface run off towards the reforestation site. Shahidul Islam and Tanaka [8] reported that agricultural activities contribute about $50 \%$ of the total pollution source of surface water by means of the higher nutrient enrichment, mainly ammonium ion $\left(\mathrm{NH}_{4}\right)$ and nitrate $\left(\mathrm{NO}_{3}\right)$. This is also supported by Delin and Landon [9] 
who thought that the different concentration of nutrient in surface run off between two sites may also be affected by elevation and the difference in recharge between two sites was due to run off at the lowland site. Nutrients also get transported and distributed in the mangrove area from the agriculture land by tidal currents [10]. Therefore, if over usage of fertilizer is being applied, the excess of nitrate is created and leaching into surface water is likely to occur. The variation of nutrient concentrations at both sites in
September and December may be affected by monsoon season. This finding was also supported by a research conducted by Nor Antonina et al. [11], where they discovered that heavy rainfall transported nutrient and antropoghenic source to the site. Wattayakorn et al. [10] also reported that a higher nutrient source in the run off occurred during the wet season compared to the dry season.

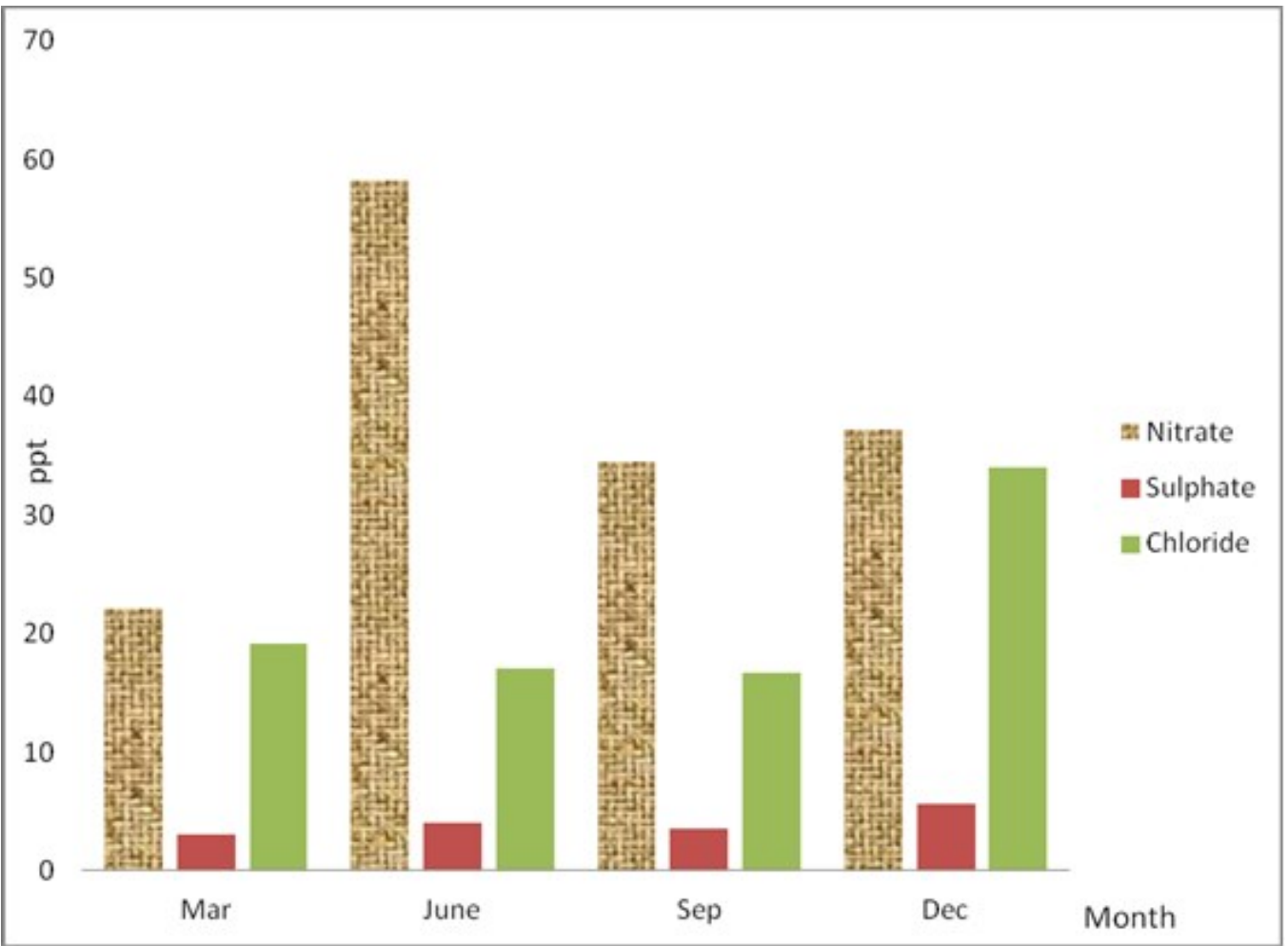

Figure 3. The average nutrient concentrations (ppt) at the reforestation site.

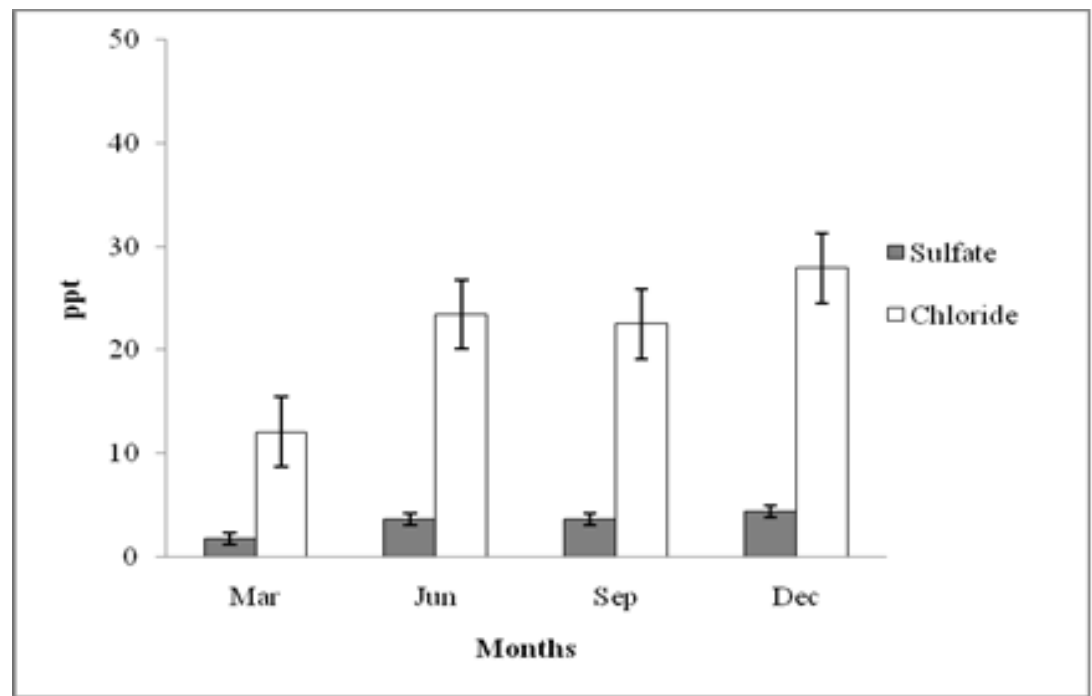

Figure 4. The average nutrient concentrations (ppt) at the natural habitat. 
Meanwhile the location of natural habitat that is far from the plantation might resulted in no nitrate was detected. It is assumed that the lost of nitrate in soil water occurred to denitrification process. This is reported in Tam and Wong [12] which indicated that the organic nitrogen, nitrite and nitrate were not detected in the leachetes from all sewage treatments because of denitricification and some of the nitrogen from sewage might have been retained in the mangrove sediment. According to Wattayakorn et al. [10] the low $\mathrm{N}: \mathrm{P}$ ratio in their sites might be due to differences in the regeneration of nitrogen and phosphorous, accumulation of nitogen in sediments or nitogen lost in sediments through denitrification. Moreover, Avicennia soils have been reported to have lower concentrations of organic matter and nitrogen than in Rhizophora soils [13]. Our observation revealed that Rhizophora sp. dominated at the remnant patches at the reforestation site while Avicennia sp. was more abundant at the natural habitat. This is strongly agreed by a survey conducted by Saraswathy et al.[14].
The comparison of heavy metal concentrations at the reforestation site and natural habitat are presented in Table 1. Higher concentrations of $\mathrm{Ca}, \mathrm{Mg}$ and $\mathrm{Mn}$ were recorded at the reforestation site showed that the site was slightly polluted. The reforestation site was located near the West Port (part of Port Klang) which is busy with shipping activities. Oil spill and waste discharge from the ships can contribute the emission of metal pollutants to the sea, and washed ashore to the coastal zone. Abdullah et al. [15] reported that shipping activities in the Straits of Malacca caused the marine pollution by attributing elements like tributyltin (TBT), $\mathrm{Pb}, \mathrm{Cu}$ and As. Additionally, lack of waste treatment in the ports and lack of effective legislation contributed to the foreign and domestic ships being discharge their oily waste to the sea [8]. Naturally $\mathrm{Ca}$ and $\mathrm{Mg}$ are the results of rock weathering, and Calcium usually is higher than magnesium in groundwater, but when there is a seawater contamination, magnesium concentrations may be greater than calcium.

Table 1. Range data of heavy metal concentrations at the reforestation site and natural habitat.

\begin{tabular}{lll}
\hline Heavy metal $(\mathbf{m g} / \mathbf{L})$ & Reforestation site & Natural habitat \\
\hline Calcium $(\mathrm{Ca})$ & $260.28-314.81$ & $151.60-311.47$ \\
Magnesium $(\mathrm{Mg})$ & $265.47-818.71$ & $209.00-255.77$ \\
Manganese $(\mathrm{Mn})$ & $0.09-0.78$ & $0.01-0.38$ \\
Cuprum $(\mathrm{Cu})$ & $0.01-0.02$ & $0.02-0.04$ \\
Arsenic $(\mathrm{As})$ & $0.01-0.04$ & $0.01-0.05$ \\
\hline
\end{tabular}

$\mathrm{Cu}$ and As were slightly higher in the natural habitat compared to the reforestation site, although remain within the limit of Malaysia Interim Marine Water Quality by Department of Environment, Malaysia. According to Shazili et al. [16], a reliable data and studies on As and other heavy metals such as $\mathrm{Hg}$, Sn and Cr were still lacking and need to be concern due to their high bioavailability and potential toxicity to the environment.

The growth rates of mangrove seedlings are presented in Table 2. R.apiculata has better height increment in coir log treatment compared to A.alba which is $1.74 \mathrm{~cm}$ and $1.28 \mathrm{~cm}$ per month respectively but they produced 1 leaves per month on average. Whilst in the natural treatment A.alba showed better growth performance in terms of height and number of leaves compared to R.apiculata (Table 2). A very slow growth was recorded at both sites between these species compared to other previous study. According to Duarte et al., [3], the fastest growth of R.apiculata was recorded is $4.5 \mathrm{~cm}$ month-1 in the mud flat area and the slowest growth is $0.45 \mathrm{~cm}$ month-1 in the sandy area. Mohammadizadeh et al., [17] reported that Avicennia marina which was planted in lower intertidal zone had the greatest stem height (3.24 cm mth-1). Many factors contributed to slow growth of seedling such as sediment burial [7], soil particle, physical factor and nutrient and heavy metal concentrations. Hence, this study was focusing on the relationship between the seedling growth with nutrient and heavy metal as depicted in Tables 3 and 4 . 
Malaysian Journal of Science 33(2): 141-149 (2014)

Table 2. Mean \pm S.D of the growth rate of mangrove seedlings.

\begin{tabular}{|c|c|c|c|c|}
\hline Treatment & Rehabilitation site & & Natural habitat & \\
\hline Species & Height $\left(\mathrm{cm} \mathrm{mth}^{-1}\right)$ & Number of leaves & Height $\left(\mathrm{cm} \mathrm{mth}^{-1}\right)$ & Number of leaves \\
\hline A. alba & $1.28 \pm 0.83$ & $1.04 \pm 0.41$ & $2.17 \pm 1.09$ & $1.6 \pm 0.23$ \\
\hline R. apiculata & $1.74 \pm 1.09$ & $0.76 \pm 0.51$ & $0.65 \pm 0.35$ & $1.09 \pm 0.43$ \\
\hline
\end{tabular}

Table 3. Correlation coefficient (r) between the seedling growth rates and the nutrient and heavy metal concentrations in the rehabilitation site. $(* * \mathrm{P}<0.01, * \mathrm{P}<0.05, \mathrm{n} . \mathrm{s}=$ not significant $)$

\begin{tabular}{|c|c|c|c|c|}
\hline Species & Avicennia alba & & Rhizophora apiculata & \\
\hline Parameter & Height & Number of leaves & Height & Number of leaves \\
\hline \multirow[t]{2}{*}{$\overline{\text { Nitrate (ppt) }}$} & 0.483 & 0.342 & 0.156 & 0.315 \\
\hline & n.s & n.s & n.s & n.s \\
\hline \multirow[t]{2}{*}{ Sulfate (ppt) } & 0.380 & 0.195 & -0.108 & -0.242 \\
\hline & n.s & n.s & n.s & n.s \\
\hline \multirow[t]{2}{*}{ Chloride (ppt) } & 0.359 & 0.223 & -0.188 & -0.267 \\
\hline & n.s & n.s & n.s & n.s \\
\hline \multirow[t]{2}{*}{ Calcium (mg/L) } & 0.582 & 0.633 & 0.992 & 0.635 \\
\hline & n.s & n.s & $* *$ & n.s \\
\hline \multirow{2}{*}{$\operatorname{Mg}(\mathrm{mg} / \mathrm{L})$} & 0.991 & 0.993 & 0.509 & -0.304 \\
\hline & $* *$ & $* *$ & n.s & n.s \\
\hline \multirow[t]{2}{*}{$\operatorname{Mn}(\mathrm{mg} / \mathrm{L})$} & 0.260 & 0.323 & -0.272 & -0.456 \\
\hline & n.s & n.s & n.s & n.s \\
\hline \multirow[t]{2}{*}{$\mathrm{Cu}(\mathrm{mg} / \mathrm{L})$} & 0.632 & 0.666 & 0.997 & 0.577 \\
\hline & n.s & n.s & $* *$ & n.s \\
\hline \multirow[t]{2}{*}{ As $(\mathrm{mg} / \mathrm{L})$} & 0.130 & 0.234 & 0.746 & 0.816 \\
\hline & n.s & n.s & n.s & n.s \\
\hline
\end{tabular}

Table 4. Correlation coefficient (r) between the seedling growth rates and the nutrient and heavy metal concentrations in in the natural habitat. $(* * \mathrm{P}<0.01, * \mathrm{P}<0.05, \mathrm{n} . \mathrm{s}=$ not significant $)$

\begin{tabular}{|c|c|c|c|c|}
\hline Species & Avicennia alba & & Rhizophora apiculata & \\
\hline Parameter & Height & Number of leaves & $\underline{\text { Height }}$ & Number of leaves \\
\hline \multirow[t]{2}{*}{ Sulfate (ppt) } & -0.346 & -0.857 & -0.544 & -0.415 \\
\hline & n.s & $* *$ & n.s & n.s \\
\hline \multirow[t]{2}{*}{ Chloride (ppt) } & -0.256 & -0.873 & -0.618 & -0.495 \\
\hline & n.s & $* *$ & n.s & n.s \\
\hline \multirow[t]{2}{*}{ Calcium (mg/L) } & 0.692 & 0.393 & -0.072 & -0.035 \\
\hline & n.s & n.s & n.s & n.s \\
\hline \multirow[t]{2}{*}{$\operatorname{Mg}(\mathrm{mg} / \mathrm{L})$} & 0.685 & 0.436 & -0.169 & -0.122 \\
\hline & n.s & n.s & n.s & n.s \\
\hline \multirow[t]{2}{*}{$\operatorname{Mn}(\mathrm{mg} / \mathrm{L})$} & 0.607 & 0.485 & -0.002 & 0.047 \\
\hline & n.s & n.s & n.s & n.s \\
\hline \multirow[t]{2}{*}{$\mathrm{Cu}(\mathrm{mg} / \mathrm{L})$} & -0.643 & -0.583 & 0.123 & 0.101 \\
\hline & n.s & n.s & n.s & n.s \\
\hline \multirow[t]{2}{*}{ As (mg/L) } & 0.597 & 0.390 & -0.229 & -0.185 \\
\hline & n.s & n.s & n.s & n.s \\
\hline
\end{tabular}


At the reforestation site, there is a significant correlation between $\mathrm{Mg}$ and growth of A.alba. The concentrations of $\mathrm{Mg}$ showed positive correlation with growth rate $(\mathrm{P}<0.01)$ in term of stem height and number of leaves $(r=0.991$ and $r=0.993$ respectively). Meanwhile, $\mathrm{Ca}$ and $\mathrm{Cu}$ showed positive correlation in stem height of $R$. apiculata which $\mathrm{P}<0.01(\mathrm{r}=0.992$ and $r=0.997$ respectively). Mg fertilizer was widely used in palm oil plantation in order to increase the palm oil yields. $\mathrm{Mg}$ is the central element in chlorophyll and is therefore essential for efficient photosynthesis [18]. During the heavy rainfall the surface run off from the plantation brought the contaminants to the sea. The higher $\mathrm{Mg}$ concentration at the reforestation site might affect the seedling growth which contributed to lower increment of height and number of leaves in coir log treatment. Furthermore, mangrove soil has a high cation exchange capacity with $\mathrm{Mg}$ and $\mathrm{Ca}$ as predominant cations.

There were no significant difference in other nutrient (nitrate, sulfate and chloride) and heavy metal (Mn and As) with the plant growth in both species. These inferred that nitrate, sulfate, chloride, Mn and As did not affect the seedling growth. Contrast with Youssef and Saenger [19] who found that growth of A. marina, $B$. gymnorrhiza and A. corniculatum was affected by reduced $\mathrm{Fe}$ and $\mathrm{Mn}$. Meanwhile, $\mathrm{Ca}$ concentration at the reforestation site contributed to a higher in stem increment of $R$. apiculata. $\mathrm{Ca}$ is essential elements in plant growth. However Table 3 showed that height of $R$. apiculata was positively correlated with $\mathrm{Cu}(\mathrm{r}=$ $0.997, \mathrm{P}<0.01)$. It showed that the increases of $\mathrm{Cu}$ level in soil affected the increment of stem height in $R$. apiculata. However, $\mathrm{Cu}$ can be very toxicity to plants and other marine life. Yim and Tam [20] clarified that high heavy metal concentration of $\mathrm{Cu}$ as well as $\mathrm{Zn}, \mathrm{Cd}$, $\mathrm{Cr}$ and $\mathrm{Ni}$ significantly reduced leaf number and stem basal diameter in B. gymnorrhiza just after 63 days of wastewater treatment. Whilst, A. marina seedlings were found to be more relatively tolerant to $\mathrm{Cu}$ and others applied metals $(\mathrm{Zn}$ and $\mathrm{Pb})$ in leaf tissues as reported by Macfarlane and Burchett [21]. When uptake of metals exceeds the metabolic requirements; a toxic impact may be expected [21].

In the natural habitat, only sulfate and chloride have a significant correlation in number of leaves of $A$. alba. The Pearson correlation showed that the sulfate and chloride were negatively correlated with leaf number ( $\mathrm{P}$ $<0.01, \mathrm{r}=-0.857$ and $\mathrm{r}=-0.873$ respectively). This indicated that the leaf number will increase with the lower concentration of sulfate and chloride in soil. The growth rates of $R$. apiculata in the natural habitat were not affected by nutrient and heavy metal concentrations (Table 4). The lower growth rate of $R$. apiculata might be due to higher concentration of $\mathrm{Cu}$ and $\mathrm{As}$ in the soil compared to the reforestation site which is indirectly affected the seedling growth. According to Gonghua et al., [22], chloride accumulation in soil influence on reducing the nitrification rate of ammonium fertilizers in rice field management; but nitrification is important to supply the nitrogen to plant growth. A previous study reported that very low sulfate ion content in the nutrient solution reduced the shoot dry weight, the photosynthetic rate, chlorophyll content, and the total number of fruits in tomato plants [23]. They concluded that accumulation of sulfates does not harmful to the plants when the ratio between sulfate ions and major elements such as $\mathrm{Ca}, \mathrm{K}$ and $\mathrm{Mg}$ in the nutrient solution is the appropriate one. Their finding were opposite with our result where mangrove seedlings may get affected by high concentration of sulfate in soil. Thus, further study on mangrove uptake of nutrient content is needed in our study.

\section{CONCLUSION}

This study has shown the relationship between the presence of nutrients and heavy metals and mangrove seedling growths at the reforestation site and natural habitat. At the reforestation site, nutrient and heavy metal are mostly derived from water surface run off from the nearest palm oil plantation, shipping activities and domestic wastes from the nearest settlements. It was found that $A$. alba showed a positive correlation with $\mathrm{Mg}$ at the reforestation site and with sulfate and chloride in natural habitat. At the reforestation site $R$. apiculata showed positive correlation with $\mathrm{Ca}$ and $\mathrm{Cu}$ and did not record any significant correlation with any elements in the natural habitat. Thus, the higher concentrations of heavy metals contribute to marine pollution and subsequently can affect mangrove seedling growth.

\section{ACKNOWLEDGEMENT}

The authors are thankful for the Postgraduate Research Fund from University of Malaya and research funds from the R\&D Department, Sime Darby Plantation Berhad for conducting this project. Thanks are also due to the Institute of Biological Sciences, University of Malaya for providing transportation and instrumentation for this study. The assistance of several staff members at the Mangrove Research Centre, Carey Island, during field studies, is greatly appreciated. 


\section{REFERENCES}

1. Thia-Eng, C., Ingrid, R. L., Gorre, S., Adrian Ross, Stella Regina Bernard, Bresilda Gervacio, Corazon Ebarva, M., (2000). The Malacca Straits. Pollution Bulletin. 41(1-6): 160-178.

2. Sharina, G., (1999). Malacca: The impact of transportation on wildlife in the Malacca Strait. TED Case studies. 9 (3).

3. Duarte, C. M., Geertz-Hansen, O., Thampanya, U., Terrados, J., Fortes, M. D., Kamp-Nielsen, L., Borum, J., Boromthanarath, S., (1998). Relationship between sediment conditions and mangrove Rhizophora apiculata seedling growth and nutrient status. Marine Ecology Progress Series 175: 277283.

4. Ghazali, N. H. M., (2006). Coastal erosion and reclamation in Malaysia. Aquatic Ecosystem Health \& Management 9(2): 237-247.

5. Forestry Department Peninsular Malaysia. 2008. Annual Report 2008. Forestry Department Peninsular Malaysia, Kuala Lumpur.

6. Golden Hope Plantations Berhad. 2006. Carey Island a golden heritage: Reliving history, preserving legacy. Golden Hope Plantations Berhad, Kuala Lumpur.

7. Affandi, N. A., Kamali, B., Mohd Zakaria, R., Mohd Tamin, N., Hashim, R., (2010). Early growth and survival of Avicennia alba seedlings under excessive sedimentation. Scientific, Research \& Essay 5(18): 2801-2805.

8. Shahidul Islam, M., Tanaka, M., (2004). Impacts of pollution on coastal and marine ecosystems including coastal and marine fisheries and approach for management: A review and synthesis. Marine Pollution Bulletin. 48: 624-649.

9. Delin, G. N., Landon, M. K., (2002). Effects of surface run-off on the transport of agricultural chemicals to ground water in a sandplain setting. The Science of the Total Environment 295: 143-155.

10. Wattayakorn, G., Prapong, P., Aksornkoae, S., 1994. Status of nutrients in mangrove soil and water at Phang-Nga and Ban Don Bays, Thailand. In Saudara, S. Wilkinson, C. R. and Chou L. M. (Ed), Proceeding, Third ASEAN-Australia Symposium on Living Coastal Resources, pp 363-372. Bangkok, Thailand.
11. Nor Antonina, A., Noor Azhar, M. S., Lokman, H. M., Siti Zauyah, D., Kamaruzzaman, Y., Shamsuddin, A., (2007). Heavy metal distribution of the South China Sea continental shelf sediments off Sabah and Sarawak coastlines. Aquatic Ecosystem Health \& Management 10(1): 57-67.

12. Tam, N. F. Y. and Wong, Y. S., (1994). Nutrient and heavy metal retention in mangrove sediment receiving wastewater. Wat. Science Technology 29(4): 193-200.

13. Alongi, D. M., (2009). The energetics of mangrove forests. Springer Science, Australia.

14. Saraswathy, R., Rozainah, M. Z., Redzwan, G., (2009). Diversity and biomass estimation of mangrove trees on Carey Islnad, Malaysia. Eco. Env. \& Cons. 15(2): 205-211.

15. Abdullah, A. R., Tahir, N. M., Tong, S. L., Hoque, T. M., Sulaiman, A. H., (1999). The GEF/UNDP/IMO Malacca Straits Demonstration Project: Sources of pollution. Mar. Pollut. Bull. 39: 229-233.

16. Shazili, N. A. M, Yunus, K., Ahmad, A. S., Abdullah, N., Abd Rashid, M. K., (2006). Heavy metal pollution status in the Malaysian aquatic environment. Aquatic Ecosystem Health \& Management 9(2): 137-145.

17. Mohammadizadeh, M., Farshchi, P., Danehkar, A., Mahmoodi-Madjdabi, M., Hassani, M., Mohammadizadeh. F., (2009). Interactive effect of planting distance, irrigation type and intertidal zone on the growth of grey mangrove seedlings in Qeshm Island, Iran. Journal of Tropical Forest Science 21(2): 147-155.

18. Rankine, I., Fairhurst T.H., (1999). Management of Phosphorus, Potassium and Magnesium in mature oil palm. Better Crops International 13 (1): 10-15.

19. Youssef, T., Saenger, P., (1998). Photosynthetic gas exchange and accumulation of phytotoxins in mangrove seedlings in response to soil physicchemical characteristics associated with waterlogging. Tree Physiol. 18: 317-324.

20. Yim, M.W., Tam, N.F.Y., (1999). Effects of wastewater-borne heavy metals on mangrove plants and soil microbial activities. Marine Pollution Bulletin 39: 179-186. 
21. Mac Farlane, G. R., Burchett, M. D., (2001). Photosynthetic pigments and peroxidase activity as indicators of heavy metal stress in the grey mangrove, Avicennia marina (Forsk.) Vierh. Marine Pollution Bulletin 42(3): 233-240.

22. Gonghua, X., Hillel, M., Jorge, T., Uzi, K., (1999). Advances in Chloride nutrition of plants. Advances in Agronomy 68: 97-110.
23. Lopez, J., Tremblay, N., Voogt, W., Sylvain, D., Gosselin, A., (1996). Effects of varying growth, physiology sulfate concentrations on and yield of the greenhouse tomato. Scientia Horticulturae 67: 207-217. 